\title{
A comparative analysis of remittance behaviour between East European and North African migrants
}

\author{
Monica Roman, Academy of Economic Studies Bucharest \\ Bogdan Ileanu, Academy of Economic Studies Bucharest \\ Mihai Roman, Academy of Economic Studies Bucharest
}

\begin{abstract}
The labour migration in Europe is a phenomenon with multiple effects, both positive and negative. Money sent by emigrants to their families is increasing their quality of life and has positive effects on the family relations; therefore it can be identified an increasing interest in the literature in studying such aspects.

The purpose of the paper is to conduct a comparative analysis of the migrants' propensity to sending money to the origin country.

The study is based on data coming from the National Immigrant Survey of Spain (in Spanish: Encuesta Nacional de Inmigrantes - 2007). A total of 15,475 interviews were carried out. Moroccans, Romanians, and Ecuadorians represent $30 \%$ of the total number of immigrants resident in Spain.

We employ a binary logistic regression model in order to identify the impact of sociodemographical factors on the probability of sending money abroad from Spain. Our aim is to identify cultural discrepancies in remittances sending, according to origin of migrants. We are mainly focusing on two large groups of respondents, which are North African and South Eastern Europe migrants. The variables employed are age of respondent, education, Intention to return in the country of origin, The period spent in Spain, gender of respondent, and the relation with the country of origin defined by the frequency of visits in the country. We identified similar patterns and also significant differences among the two groups.
\end{abstract}

JEL codes: F22, I31, R23

\section{Introduction}

The labour migration in Europe is a phenomenon with multiple effects, both positive and negative. Money sent by emigrants to their families is increasing their quality of life and has positive effects on the family relations. Remittances are also an important source of external funding for developing countries. They rank only behind foreign direct investment, and are much higher in magnitude than total official development assistance. Therefore, it can be identified an increasing interest in the literature in studying such aspects.

According to World Bank Statistics, the top recipients in terms of the share of remittances in GDP in 2008 include many smaller economies such as Tajikistan, Tonga, Moldova, Kyrgyz Republic, Lesotho, Samoa and Lebanon; in these countries remittances exceeded a quarter of the GDP, providing a lifeline to the poor.

Important remittances inflows are found in 2008 in North African countries such are Tunisia (4.9\% of GDP), Algeria, Egypt (5.9\%), Lebanon (23.7 \% of GDP), Syrian Arab Republic (2.2\% of GDP), and Morocco ( $9 \%$ of GDP). In Europe, among the former communist countries -which are the most significant beneficiaries of the money sent by emigrants- we find Romania (5.1\% of GDP), Bulgaria (5.4\% of GDP), Ukraine $(3.2 \%$ of GDP), Serbia (13.9 \% of GDP), Macedonians (4.5\% of GDP), Croatia (2.7 \% of GDP).

Due to increasing role of remittance in the context of financial crisis- a major source of income for households in developing countries-, identifying the true motivations behind remittance behavior is crucial to predict the long term effect of migration on the households and at a macro-level its influence on the sending society overall. Furthermore, the motivations 
behind remittance behavior have significant implications for public policy, especially in countries that rely heavily on remittance from migrants and lack social security transfers or other welfare programs.

The purpose of the paper is to conduct a comparative analysis of the migrants' propensity to send money to the origin country. The remittance behaviour has been proven to be quite diversified in different parts of the world and our primary objective is to explore the similarities and dissimilarities existing between two large groups of emigrants in Spain: Eastern European and North African emigrants. For this purpose, we explore an important data source that is provided by the National Immigrant Survey of Spain.

Within a multivariate context, we seek to uncover the factors that would determine the remittance decision and the magnitude of these factors. Logistic regression is applied in order to establish the significance of origin in decision to remit and then to identify the statistical significant factors that determine emigrants from the two groups to remit.

The rest of the paper is structured as follows. Section 2 offers a brief review of the relevant theories on remittances. Section 3 details the econometric methodology adopted and explains the data set used. In this section are also explained the basic hypothesis. In Section 4 are presented the empirical results and concluding notes complete the paper.

\section{Literature review}

The literature on the remittance behaviour of households is substantial. We have identified two large categories of studies. Firstly, there are some studies that consider the macroeconomic determinants of remittances (see Schiopu and Siegfried, 2006), and are conducted based on macroeconomic data. Secondly, there are studies focusing on the microeconomic determinants of remittance motives and we shall refere to these ones mostly.

The existing debate in remittance literature is determined by the quality of used data. As it was notices by Rapoport and Docquier (2005), "at a macro level, it is not always possible to test appropriately for the macroeconomic impact of remittances because of poor data quality; at a micro level, it is extremely difficult to discriminate between competing theories of remittance".

The Eastern European countries are characterized by a poor quality of data on migration. In Romania, for instance, statistical data on migration captures only the regular emigrants who change their permanent residence. Labour migration is hard to quantify, although in the late years it become the most important component of Romanian migration. In this respect, the macro data on remittances in former communist countries from EE are very few compared to other developing countries.

Considering the methods involved in the existing papers on the determinants of remittances, it is easy to notice that a large variety of methodologies have been used. In recent papers the main methodological distinction is made between modelling the determinants of remittances as a one-stage decision (Tobit, logistic regression analysis) where the decision to remit and the amount of remittances are made together or as a Heckmann two-stage approach (Probit and corrected OLS) where the model separates between the decision to remit and the subsequent decision on how much to remit.

René Houle and Grant Schellenberg (2008) use Logistic regression for remit propensity and OLS regression for the magnitude of the remittances. Heering, van der Erf and, van Wissen (2004) apply logistic regression in order to analyze the migration intensions and its determinants in Morocco. The results of this study support the analytical gender-specific approach of migration intentions among Moroccan non-migrants. Huynh Truong Huy (2009) apply logistic regression in order to analyze the determinants of migration decision in Vietnam, controlling for ethnic groups. Lerch, Dahinden and Wanner (2007) apply logistic regression to analyze the determinants of remittance decision of Serbian Migrants living in Switzerland. The 
same method is used in order to identify the determinants of the amount remitted.

\section{Method and data}

Most previous studies of migration often examined the determinants of decision to remit associated with basic information from both family and individual migrant. As it was mentioned in the previous section, authors such are are Holst and Schrooten (2006), Richard (2001), used the probability model, namely probit or logistic model to estimate the likelihood of decision to migrate or to remit; these are most common techniques for estimating model with a dichotomous dependent variable.

We employ a binary logistic regression model in order to identify the impact of sociodemographical factors on the probability of sending money abroad from Spain.

In our study, the binary dependent variable in the model is whether a person is sending money to the money country or not, specifically 1 denotes the individual is remitting and 0 denotes otherwise. We are mainly focusing on two large groups of respondents, which are North African and South Eastern Europe migrants. The regression model will be predicting the logit, that is, the natural log of the odds of having made one or the other decision. That is,

$$
\ln (O \hat{D} D S)=\ln \left(\frac{\hat{Y}}{1-\hat{Y}}\right)=\hat{a}+\hat{b} X,
$$

where

$\hat{Y}$ is the predicted probability of the event which is coded with 1 (decision to remit) rather than with 0 (decision to not remit),

$1-\hat{Y}$ is the predicted probability of the other decision, and

$\mathrm{X}$ is predictor variable.

In theoretically, the odds are often used to express the predicted change of a unit increase in the corresponding independent variables. For example, if the odd less than one corresponds to decrease; if it is more than one corresponds to increase; and if it is equals to one meaning that unit change in that independent variable does not affect the dependent variable.

The study is based on data coming from the National Immigrant Survey of Spain (in Spanish: Encuesta Nacional de Inmigrantes - 2007).

When looking at the characteristics of migrants according to origin, the ENI points to the existence of two general migratory typologies. On the one hand, persons coming from Andean, African and Eastern European countries have all the earmarks of what might be called 'economic migrants'. They are young, they have come recently, they work in relatively lowskilled jobs and they participate in tightly knit ethnic networks.

On the other hand, immigrants coming from developed countries are quite different, with high levels of education, important proportions of people who have come to Spain to retire.

\section{Results from logistic regressions}

We took into account only the persons older than 16 because in the economic process they are able to have a legal activity. We divided the remaining sample in the two population analyzed in present study. North African migrants include all North African language speakers even if they are not leaving in a North African country. Few categories of emigrants included here are: Moroccans, Tunisians, Algerians, Egyptians, Libyans and Eastern Europeans migrants which include a more heterogeneous population composed in general by Romanians, Bulgarians, Russians, Ukrainians, Moldavians, Serbians, Macedonians, Croatians, and Hungarians.

Our sample includes 15475 observations. The empirical analysis proceeds in two stages 
using SPSS. First, we run a logistic regression using all the observations in the sample. We intend to find out what variables are significant in remittances behaviour and if Nationality has an important influence in migrants' decision to remit.

In the second stage, our core questions is if there are any observable differences between the two important groups of emigrants, in respect with remitting decision: the group of emigrants coming from North Africa and the group of emigrants coming from Eastern European countries.

The set of independent variables involved in the model are:

\section{Income}

To capture the influence of the income of the migrant, the net income from the last month is employed. The values were used as natural logarithms. Income distribution is similar in the two groups, 73,4\% of African migrants have incomes between 500 and 1500 euros and 75,9\% of Europeans have incomes in the same interval.

Age

According to the theoretical literature, the age of the remitter plays an important role. (for instance, Merkle \& Zimmermann 1992).

\section{Education}

The value of the human capital of the migrant is reflected in years of education. If $68,5 \%$ of Eastern Europeans have secondary level of studies finished only $51 \%$ of North African migrants have secondary cycle graduated. On the other hand the percentage of North African migrants which have only the primary education is almost 3 times higher compared to the same percentage of Eastern Europeans migrants.

\section{Gender}

Many empirical studies report a significant influence of gender on remittances. We use a dummy variable to check for this effect here. The variable "gender" is 1 in the case of a female remitter and 0 in the case of a male remitter. There is an equilibrate distribution between men and women in the general sample and among Eastern Europeans migrants. The significant difference is present for North African migrants, where more than $60 \%$ of migrants are men.

\section{Origin}

Nationality, country of origin and the specific migration background might influence the remittances and transfer behavior. The origin of a migrant is captured in the model by the country of birth.

\section{Visits home}

One important basis for remittances is personal contacts to the home country. Here we assume that visits to the country of origin are an important indicator for such personal links. Therefore we expect a positive impact of the visit on remittances. We also control for the future plans of migrants, using a dummy for the decision of moving back in the home country in the next 5 years. We assume that a person with intention to move back will have a smaller probability to remit compared to a person who is willing to remain in Spain.

\section{Household}

A strong argument for remitting is the dimension of the family left in the country of origin. We assume that the propensity to remit is increasing with the number of children living at home and if the wife/husband is there. European migrants have in general smaller number of children than North African families. This difference could be explained by differences regarding tradition and religion. Also the number of children could be an effect of other social characteristics such as marital status and economic power given by income. We may observe that $64 \%$ of North African respondents are married compared to only $53 \%$ of Europeans. 
The length of staying in Spain and the owing an affaire in Spain were included in the logistic regression model, as well. A significant difference between the two categories of migrants could be observed analyzing the period spent in Spain. 96\% of eastern Europeans have less than 10 years spent in Spain, while 22\% of North Africans have more than 20 years.

Foreigners living in Spain are not homogenous group concerning their remittance behavior. In this respect, nationality is a significant factor, as it is shown in table 1.

Tabel 1. Results from logistic regression models

\begin{tabular}{|c|c|c|c|c|c|c|}
\hline \multirow[t]{2}{*}{ Model } & \multicolumn{2}{|c|}{ I. Total sample } & \multicolumn{2}{|c|}{$\begin{array}{l}\text { II. North African } \\
\text { emigrants }\end{array}$} & \multicolumn{2}{|c|}{$\begin{array}{l}\text { III. East Europeans } \\
\text { emigrants }\end{array}$} \\
\hline & B & $\begin{array}{c}\operatorname{Exp}(\mathrm{B} \\
)\end{array}$ & $\mathrm{B}$ & $\operatorname{Exp}(\mathrm{B})$ & B & $\operatorname{Exp}(B)$ \\
\hline lnIncome &, 068 & 1,070 & ,351 & 1,420 &, $285 * *$ & 1,329 \\
\hline gender & ,098 & 1,103 &,$- 579 * * *$ & ,561 &,- 024 & ,977 \\
\hline Bussiness owner & ,408** & 1,504 &,$- 794 * *$ & , 452 & 254 & 1,289 \\
\hline $\begin{array}{l}\text { Lenght of } \\
\text { migration }\end{array}$ &,$- 066 * * *$ & ,936 &,$- 086 * * *$ & ,917 & $\begin{array}{c}-, 090 * * \\
*\end{array}$ & ,914 \\
\hline House owner &,$- 244 * * *$ & ,783 & ,424 & 1,528 & , 150 & 1,162 \\
\hline Future plans &,$- 619 * * *$ & ,538 & , 168 & 1,183 &, 332 & 1,393 \\
\hline Visit number &,$- 022 * * *$ & ,979 &,- 005 & ,995 &,- 002 & ,998 \\
\hline $\begin{array}{l}\text { Wife in origin } \\
\text { country }\end{array}$ &, $774 * * *$ & 2,168 &, $834 * * *$ & 2,303 & ,313 & 1,367 \\
\hline $\begin{array}{l}\text { Children in } \\
\text { origin country }\end{array}$ &, $828 * * *$ & 2,288 &, 703 & 2,020 & $\begin{array}{c}1,478 * * \\
*\end{array}$ & 4,385 \\
\hline Education &,$- 119 * * *$ & 887 & , 107 & 1,113 &,- 052 & ,949 \\
\hline Home country &,$- 201 * * *$ & ,818 & $\mathrm{X}$ & $X$ & $\mathrm{X}$ & $\mathrm{X}$ \\
\hline Constant & $1,620 * * *$ & 5,054 & $-1,049$ & ,237 &,- 941 & ,390 \\
\hline $\begin{array}{c}\text { No of } \\
\text { observations }\end{array}$ & \multicolumn{2}{|c|}{15139} & \multicolumn{2}{|c|}{2187} & \multicolumn{2}{|c|}{1998} \\
\hline $\begin{array}{c}\text { Nagelkerke R } \\
\text { Square }\end{array}$ & \multicolumn{2}{|c|}{0,354} & \multicolumn{2}{|c|}{0,257} & \multicolumn{2}{|c|}{0,148} \\
\hline $\begin{array}{c}\text { Cox \& Snell R } \\
\text { Square }\end{array}$ & \multicolumn{2}{|c|}{0,265} & \multicolumn{2}{|c|}{0,192} & \multicolumn{2}{|c|}{0,108} \\
\hline
\end{tabular}

Gender and income are non-significant factors, when considering the whole sample. All the other factors in logistic regression model are significant. Family connections with home country are the most influential factors. The degree of integration into the society of the host country matters in the whole population.

\section{Conclusions}

Our main findings considering the two observed subpopulations of migrants are: In both cases of the Eastern Europeans and North Africans, family ties are the most important factors that determine remittance propensity. The beneficiary of the remittances is the factor that makes the difference between the two groups. In Europeans case a person is three times more likely to remit if it has children in the origin country, while in North African case a person is more likely to remit if he has a wife in the origin country. In this last case, gender is a 
significant factor in the model and being a male increase the probability to remit. In both cases degree of integration in Spain observed through the length of staying in Spain is a significant negative factor.

We found out that the probability to remit is not dominated by income, which is nonsignificant in the global model. However, it is significant in the East Europeans case. Instead, North African migrants are more entrepreneurship oriented, since in their case owing a business is a significant positive factor in remittances behaviour.

Acknowledgements

This paper was supported by CNCSIS grant no 1829/2008: The Effects of Labor Force Migration and Demographical Structural Changes on Dynamic Economies

\section{References}

- Heering L., van der Erf R., van Wissen, L., 2004. „The Role of Family Networks and Migration Culture in the Continuation of Moroccan Emigration: A Gender Perspective" Journal of Ethnic and Migration Studies Vol. 30, No. 2, March 2004, p. 323-337

- Holst, E., Schrooten M., 2006 „Migration and Money - What determines Remittances? Evidence from Germany" DIW Berlin, SOEP, and University of Flensburg, Berlin

- Houle, R. and Schellenberg, G., „Remittance Behaviours Among Recent Immigrants in Canada", Statistics Canada, Business and Labour Market Analysis

- Huynh Truong Huy, 2009. „Rural to Urban Migration as a Household Decision: Experimental Evidences from the Mekong Delta, Vietnam”, DEPOCEN, Working Paper Series No. 2009/17

- Hoddinott, J., 1992. "A Model of Migration and Remittances Applied to Western Kenya”, Oxford Economic Papers, 46, p. 459-476.

- $\quad$ Lerch M., Dahinden J., Wanner P. 2007. „Remittance Behaviour of Serbian Migrants living in Switzerland", SFM Studies No. 51

- Lucas, Robert E. B., and Oded Stark. 1985. "Motivations to Remit: Evidence from Botswana." The Journal of Political Economy 93(5).

- $\quad$ Merkle, L. and Zimmermann, K. (1992): "Saving and Remittances: Guest Workers in West Germany”, in Klaus Zimmermann (ed.), Migration and Economic Development, Berlin: Springer-Verlag, p.55-75.

- Poirine, B., 1997. “A Theory of Remittances as an Implicit Family Loan Arrangement”, World Development, 25(4), p. 589-611

- $\quad$ Rapoport, Hillel and Frederic Docquier. 2005. "The Economics of Migrants' Remittances." The Institute for the Study of Labor (IZA) Discussion Paper No. 1531.

- $\quad$ Reher, D.; Requena, M. 2009 "The National Immigrant Survey of Spain. A new data source for migration studies in Europe", Demographic Research, 20 (12), p. 253 - 278.

- Schiopu, I., Nikolaus S, 2006. "Determinants of Workers' Remittances: Evidence from the European Neighbouring Region." European Central Bank, Working Papers Series No. 688.

- Stark, Oded, and David E. Bloom. 1985. "The New Economics of Labor Migration." The American Economic Review 75(2): p. 173-178. 